Marquette University

e-Publications@Marquette

English Faculty Research and Publications

English, Department of

9-1-2007

\title{
Messages in a Bottle: The 2007 Lion and the Unicorn Award for Excellence in North American Poetry
}

\author{
Angela Sorby \\ Marquette University, angela.sorby@marquette.edu \\ Joseph T. Thomas Jr. \\ San Diego State University \\ Richard Flynn \\ Georgia Southern University
}

Published version. The Lion and the Unicorn, Vol. 31, No. 3 (September 2007): 264-281. DOI. (C) 2007 The Johns Hopkins University Press. Used with permission. 


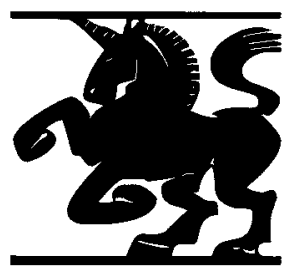

\section{Messages in a Bottle: The 2007 Lion and the Unicorn Award for Excellence in North American Poetry}

\section{Angela Sorby, Joseph T. Thomas, Jr., and Richard Flynn}

Winner: JonArno Lawson. Black Stars in a White Night Sky. Illus. Sherwin Tjia. Toronto: Pedlar Press, 2006.

Honor Books: Jorge Argueta. Talking with Mother Earth/Hablando con Madre Tierra. Illus. Lucía Angela Pérez. Toronto: Groundwood/House of Anansi, 2006.

Helen Frost. The Braid. New York: Frances Foster/Farrar Straus: 2006.

Walter Dean Myers. Jazz. Illus. Christopher Myers. New York: Holiday House, 2006.

Walter Dean Myers. Street Love. New York: Amistad/HarperTempest, 2006.

We have received more good books of poetry for this year's The Lion and the Unicorn Award for Excellence in North American Children's Poetry than in any of the previous three years. Although JonArno Lawson's Black Stars in a White Sky readily emerged as the winner, the unusually large number of solid submissions this year made narrowing down our shortlist of books quite difficult. Still, we are hesitant to conclude that we are now entering some Golden Age of children's poetry, even as we are cognizant of the always-witty Randall Jarrell's remark in his essay "The Taste of the Age" that "the people who live in a Golden Age usually go around complaining how yellow everything looks" (No Other 313). Awards such as these are intended to draw our attention to the most interesting poems published this year; unfortunately, we do not have the benefit of hindsight in determining just how the future will look back at the world of children's 
poetry in the early twenty-first century. The benefits of hindsight, especially in regard to canon formation, became clear to us when we received three reissues of children's poetry that reminded us that there is a standard of excellence for children's poetry against which we might measure contemporary efforts. While we decided that these reissues were ineligible for an award honoring new poetry, Gwendolyn Brooks's Bronzeville Boys and Girls, Richard Wilbur's Opposites, More Opposites, and a Few Differences, and Mary Ann Hoberman's The Llama Who Had No Pajama were like messages in a bottle from the mid-twentieth century, messages that reassured us that poetry expressly written for children matters.

The distinguished Mary Ann Hoberman's poems have a certain midcentury panache: more Little Black Dress than psychedelic micro-mini, they seem right for any occasion. Their charms are modern and yet steeped in a vital tradition. Some have the mysterious internal logic of nursery rhymes:

I was riding to Poughkeepsie

When I met a green-eyed gypsy,

A green-eyed Spanish gypsy

In a gold and scarlet gown.

And yet the scene is distinctly American, as the gypsy plots her course:

And she told me she was roaming

From Poughkeepsie to Wyoming

Through the West to wild Wyoming

Where the icy winds blow down ("As I Was Riding to Poughkeepsie" $65)$.

Other Hoberman classics are playfully onomatopoetic in the manner of Gertrude Stein, such as "Auk Talk," a two-lined poem that begs to be read aloud:

The raucous auk must squawk to talk.

The squawk auks squawk to talk goes AUK (58).

Moreover, her poems are educational without lapsing into didacticism; here, for example, we are breezily informed,

The tapir has a tubby torse.

$\mathrm{He}$ is not very big.

Although related to the horse,

He looks more like a pig.

If I were in the tapir's shoes

(Although I'm not, of course), 
Relation to the pig I'd choose,

Resemblance to the horse. ("Tapir" 61)

A few of her pieces are so precise about animal/human resemblances that they could run afoul of the creationists on the Kansas School Board-a danger that has not abated since mid-century. We could quote Hoberman until the cows (or tapirs) come home, but since her poems are reprints, they're eligible for our admiration but not for our award.

Just when we began to wax nostalgic for the Golden Age of the last century, the appearance of Faith Ringgold's stunningly beautiful illustrations for Brooks's 1956 collection of children's poems warned us of the dangers of that nostalgia. Ringgold's reillustration of Bronzeville Boys and Girls rights a fifty-year-old wrong when Brooks's poems were paired with the problematic illustrations of Ronni Solbert. In the original volume, the children in Solbert's illustrations, while they have vaguely African-American features, all have white faces, something to which Brooks objected to at the time. As might be expected from a major artist like Ringgold (who has produced her own excellent children's books such as the now-classic Tar Beach), the paintings for this new edition complement and enhance our understanding and enjoyment of the poetry both by emphasizing the specific historical and cultural contexts in which the poems were written and by extending those contexts to speak to us in the present. Brooks's lyric gift combines with her musical ear give us that rare thing: lyric poetry for children that avoids condescension and sentimentality, as in "Gertrude":

When I hear Marian Anderson sing,

I am a STUFFless kind of thing.

Heart is like the flying air.

I cannot find it anywhere.

Fingers tingle. I am cold

And warm and young and very old.

But, most, I am a STUFFless thing

When I hear Marian Anderson sing. (32)

Whereas this new edition will, we trust, supersede the mid-century version of Brooks's collection, Richard Wilbur's new edition of his superb "opposites" poems retains a New Yorker sophistication appropriate to its playful wit. Wilbur's drawings are a homage to those of Edward Lear, and like Lear's illustrations and verse, they have an appealing edge to them. Like Lear (and like Brooks) Wilbur remembers that childhood is not all sweetness and light. But most of all, Wilbur recognizes that the child's 
interest and fascination with language operates on complex intellectual and emotional levels:

A spell is something you are under

When put to sleep or filled with wonder.

The opposite of spell, I guess,

Is normal, waking consciousness,

In which you're not enthralled or sleepy

And things are only fairly creepy (n.p.).

We are enchanted by the spell Wilbur casts in these poems in which he recognizes that we can take pleasure in the creepiness of both ordinary waking life and the uncanny world of enchantment.

Indeed, we wish more children's poets would keep in mind the "fairly creepy" part of life, rather than belaboring the part where robins sing blandly among the broccoli. George Shannon's Busy in the Garden is attractively laid out and some of the rhymes are, well, adorable. But we suspect children, like us, will smell a rat when introduced to this book. Most children are philosophically opposed to vegetables, even when the veggies are doing a dance. We are reminded of the famous $1928 \mathrm{New}$ Yorker cartoon in which a mother urges her young daughter to eat her broccoli and the daughter replies, "I say it's spinach and I say to hell with it." It's not surprising that this caption was written by E. B. White, who knew something about writing for children.

We feel this way about nearly any book one might describe as cute or adorable. Foremost in the "I say it's spinach" department is the endless recycling of traditional rhymes. Even the better ones such as Jane Yolen's anthology This Little Piggy seem to partake of the John Newbery bookseller's tradition that values consumer goods first and poetry books second. Our inner Marxist critics want to point out the unintentional irony of the lamppost on the cover illustration pointing in opposite directions to "market" and "home" while above it, like some sick orange balloon, is a sticker announcing "FREE CD INSIDE with songs for playtime, naptime, anytime." Yes it's a beautifully made book (as are nearly all of Candlewick's books), and it is also a bestseller, but like most of the books of poetry that purport to be for young children, all it offers is an attractive package (and in this case a CD and sheet music). We desperately wish we would see something other than recycled nursery rhymes, sentimental poems about nature, and haiku published for the very young. Even when we love the sharp, lively language play - the real poetry, not just rhymed prose-of something like Once around the Sun, by Bobbi Katz, we're almost hurt by the fact that the subject matter is terribly mundane: we celebrate Halloween in October, Thanksgiving in November, etc. You just can't put edge into a calendar. 
Sentimental verse, of course, has a long and honorable (and ideologically complex) tradition in North America. But there is also a long tradition of innovative poetry. Marjorie Perloff, for instance, praises "radical artifice," in modern and postmodern verse, its attention to poetry as a "made thing," as "contrived, constructed, chosen" (Radical Artifice 27-28). We tend to favor poets who write with an awareness of that constructedness, as they tend to exercise greater care in the making of their verse. Sometimes, as with this year's winner, we see that tradition fulfilled and extended. Sometimes what looked promising at first turns out to be a tease.

Take the work of Douglas Florian. His collection of light verse called Handsprings, particularly because of his excellent illustrations, seems enticing at first, but it is ultimately unsatisfying because it turns out to be so ordinary. Handsprings is a sweet and well-written collection of poems - most lyric, some visual-musing on springtime (Handsprings, get it?). Florian's accomplished paintings make his poems pale by comparison. Yes, some of the poems are serviceable light-verse, but the rhymes and rhythms are ultimately too familiar: "I love leaves, / And I love flowers. / I love daydreaming for" (wait for it. . . . ) "hours." Only by condescending to children as immature readers who might still find "flowers/hours" an interesting rhyme can we find that kind of work passable as poetry. Too much of what we received tends toward this (low) level of language play, and that's a shame.

Handsprings, like many of the books we have received, suffers from a view of childhood that even William Wordsworth would find sentimental: Edenic, full of leaves and roots, trailing clouds of glory. Not that our view of childhood should be Hobbesian or Darwinian, but we feel that good poems - for children or adults - need some sort of tension, whether formal, thematic, or linguistic. Handsprings, again, like several other collections we received, also suffers from rather tame subject matter. Poems about the seasons (and weather and animals) fall, notoriously into the category of "things we talk about when we don't want to offend anyone." Furthermore, like the vast majority of visual poets for children, Florian is just too literal minded for his own good (or the good of his poems): a line about grinning ("My grin is growing roomy") is, unsurprisingly, curved into the shape of a grin. Likewise, a poem about rain features lines drifting vertically down the page. And it is this poem, "Rain Reign," which speaks to another, larger, problem we find in those who craft visual poems for children: they all too often seem unaware of the rich tradition of visual poetry for adults. "Rain Reign," which begins, "each time it rains / each time it pours / we hurry, scurry/ fast indoors," is formatted much like Apollinaire's famous "Il Pleut,"(Fig.1) typographically arranged to resemble rain showers. While we can't determine for certain whether Florian is aware of Apollinaire's 


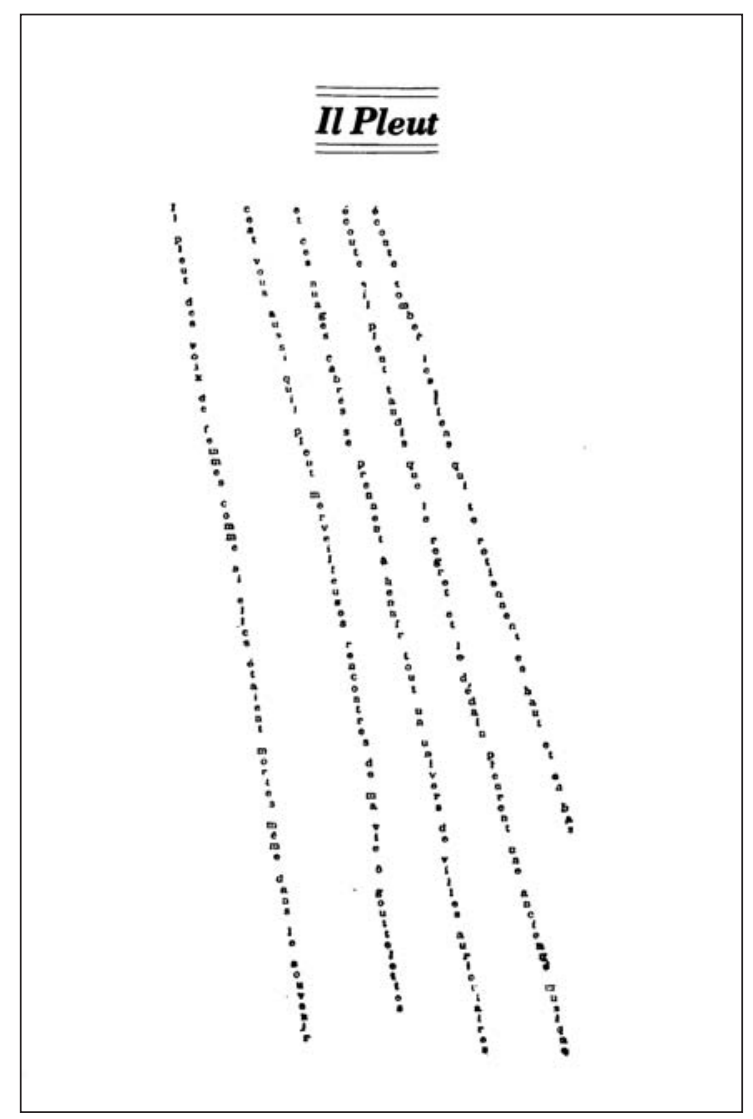

Figure 1. "Il Pleut," from Calligrammes by Guillaume Apollinaire (1916).

nearly one hundred-year-old poem, we can say that while it nods to the subject and the look of the original, it otherwise fails to engage "Il Pleut" or the tradition of visual poetry on any but the most superficial level. We can say with some confidence that the surreal impulses in Apollinaire's poem resist the very pedestrianism that limits Florian's effort.

Much more striking in their ambition and willingness to experiment are our honor books, especially Helen Frost's The Braid. Frost's work appears on our short list for the second time and she remains a stellar poet who takes children's verse seriously qua verse. The Braid's textures of language cry out to be noticed across multiple and within single poems. It is a technical marvel that contains many lovely lines: 
I grow silent, breathing in the smell of her wool shawl, the smell of peat smoke and the sea, the sour smell where Willie spat up on her shoulder after breakfast. (4)

The assonance of "peat" and "sea," the (maybe over-familiar?) suggestion of water via the repetition of the sibilant $s$, the music of "sour smell where" and the nice juxtaposition of "sour" vomit and "breakfast" works nicely. Her narrative poems are interspersed with lyric poems - an effective technique that forces us to linger on telling details:

A table absorbs written thoughts

(slight indentations in its wood), and holds within its sturdiness echoes of the conversations that go on around it ... (50)

These lyrics add a visceral dimension to the lives of the characters, a group of nineteenth-century Scottish peasants who immigrate to Canada. Sarah, the one daughter who stays behind on Mingulay, has a love affair with a fisherman named Murdo, but perhaps even more of a love affair with her impoverished, windswept environment:

Large storm clouds loom in the distance. Whitecaps roughen near the sea. I've come with James and Angus to the cliffs. Birds are coming back-look here-a pair of puffins meets after six months at sea. They take shelter together in their burrow. I remember Murdo, that morning when we walked together and he gave me a puffin egg. (39)

Meanwhile, her sister Jeannie pluckily builds a life for her family on Cape Breton:

I've made a bench out of rough plank and two large rocks. In the room here beside it, I want to build a simple table for us to eat and sew . . . (48)

The two girls' stories are told in alternating voices, although the two voices tend to sound somewhat alike because of the demands of Frost's poetic form. The formal constraints also sometimes slow the storyline, though things do pick up steam when the girls get embroiled with boyfriends and, in one case, an unexpected pregnancy. But The Braid is essentially poetic, not plot-driven: it evokes a salty, northerly landscape and invites its readers to travel, in the words of the old sea chantey, "home/to Mingulay."

One of our favorite books this year is Jazz by Walter Dean Myers. The opening poem, "Jazz," is a tad clichéd in its rendering of the black musician, writing him (and it is a him: "A black man's drum / Speaks / Love") much in the same way Amiri Baraka (then LeRoi Jones) does in Blues People, suggesting that "White is then not 'right,' as the old blues 
had it, but a liability, since the culture of white precludes the possession of the Negro "soul'" (219-20). The poem ends, almost predictably, "Work songs / Gospel / Triumph / Despair / Voices / Lifted / From the soul." But it gets much better once the general is dropped and the particulars start to sing. The second poem, "Louie, Louie, How you Play so Sweet?" (a great title) is a lyrical romp:

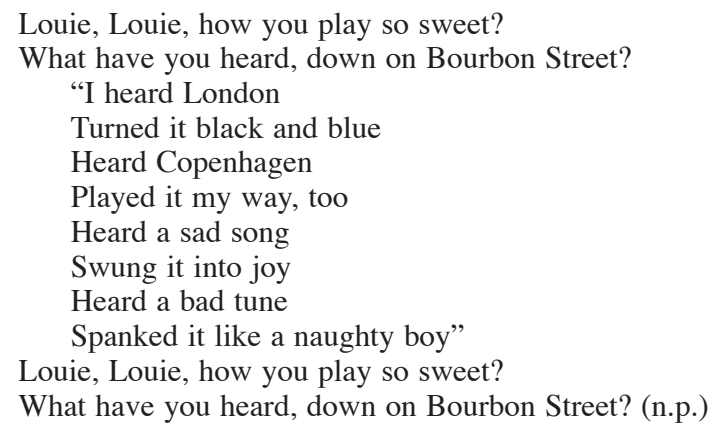

The last line spoken by Armstrong is a wonder, and the ambiguity is especially rich: either Louie is spanking the tune as if it is a naughty boy, or, rather, he's the naughty boy, spanking the tune as only a naughty boy can. This ambiguity recalls the first two lines of his response, "I heard London / Turned it black and blue," turning the music and life of London black, bluesin' up this metonym for not only Western imperialism, but also conventional Anglo poetry, the poetic norms called into question by a line of poets stretching back to Langston Hughes and his blues poetry experiments. Yet this is not a meek transformation of something good into something different, but a violent, powerful act; yes, he turns London as a final couplet turns the traditional English sonnet, but he also beat it "black and blue," beat it like a drummer, like a boxer, like a street kid from Uptown New Orleans.

However, a case can be made against the book. Although Myers obviously knows how to turn a phrase, something about the book is less than original. Just last year, the winner of The Lion and the Unicorn Award was Wynton Marsalis's Jazz ABC, another jazz book, and in this year's batch we also received Jonah Winter's Dizzy (which isn't in the same league as Myers's or Marsalis's work). It seems to us that jazz, unfortunately, has become a "safe" way to celebrate African American culture, much like the constant stream of books about Martin Luther King or Rosa Parks. Jazz has become distant, historical, fit more for the museum than the contemporary lives of young people. While there is a great deal of edgy jazz out there, most of what we see of it in children's books is sanitized; the transgressive nature of the music and many of its performers is essentially 
white-washed. Back when Langston Hughes wrote blues and jazz poems, these musical styles were emergent. His use of the blues form was novel and experimental. Like the jazz and blues of the time, Hughes's poems had edge. They expressed something essential about mid-century American culture. Not so today.

Nevertheless, as with the earlier Myers collaborations with his extremely talented son Christopher, Jazz is ultimately a winner in part because of its intelligent design, but most emphatically because Myers senior has an excellent ear. By contrast, the Tin Ear award for 2007 goes to Diane Z. Shore and Jessica Alexander for This Is the Dream, a book that invokes "The House That Jack Built" in plodding anapestic tetrameter to tell (very poorly) the story of segregation and civil rights:

This is the school, where the doors open wide, and the children are learning together inside about students and marchers and leaders who fought to make right what was wrong. Without violence they sought to make changes together, establish new laws.

With many small triumphs they strengthened their cause. (n.p.)

Angela Sorby was led to speculate that she might be able to pick up some extra cash with a whole series of "let's trivialize and clunkify" history books of this sort:

This is the prison on wee Robbin Island

Where Nelson Mandela was seldom seen smilin'

or

This is the sit-in where Mahatma Gandhi

Thought that non-violence just might come in handhi.

In all seriousness, however, our discussions about Myers's Jazz and the prevalence of jazz-themed books, led Angela Sorby to note that there ought to be more children's poetry rooted in hip hop and rap. Yes, some hip hop is not what one would immediately consider child-friendly, but it surely could be. In particular, Angela wished we had more children's poetry using the hip hop idiom to celebrate and interrogate contemporary African American culture. For this reason, she preferred Street Love, another of Myers's books, to Jazz. It is a testament to Myers's ability as a poet that he has produced two quite compelling books of poetry this year, and while Jazz looks back, Street Love is utterly present tense and doesn't mince words. At the same time, Street Love is fairly melodramatic. The author's choice to write in verse, as opposed to prose, results in the emotional moments constantly being hyped in order to give each poem 
a core. Yet with so many poems, you get page after page of heightened emotions with no down time.

Sappy cover art aside, Street Love is an accomplished book. Even if the narrative is not as gripping as it might be, and even if all the poems are not consistently excellent, overall the sounds are great, and the line breaks compelling. It begins evocatively:

Autumn in Harlem.

Fume-choked leaves, already

Yellowed, crack in the late September

Breeze. Weeds, city tough, city brittle,

Push defiantly along the concrete edges

Of Malcolm X Boulevard. On 137th Street

A toothless sidewalk vendor neatly stacks

His dark knit caps besides the plastic cell

Phone covers ... (1)

Autumn - a weighted metaphor for old age, endings close by, the coming of winter-is "already" here, even as the "Fume-choked leaves" are "already / Yellowed." The internal rhyme of "Breeze" and "weeds" is nicely punctuated by an interrupting period. The word "edges," right above "Street" and "stacks," makes an interesting vertical "stack," especially as the next word in the horizontal list is "plastic cell," suggesting artificiality (this isn't a living cell-it's a plastic one) even as it evokes prison, or being imprisoned. Here we see the kind of love/hate relationship one can have with a city; we see how complicated and darkly knitted "Street Love" can be, as the city streets can represent hope and despair. Despite the cell phones and other markers of the present, we can't help but be reminded of Stevie Wonder's "Living for the City" (1973) or perhaps The Crusaders's 1979 recording of "Street Life" (written by Will Jennings and Joe Sample):

Street life, for a nickel, for a dime

Street life, but you better not get old

Or you're gonna feel the cold

There's always love for sale

A grown up fairy tale

Of course, Myers gives us an adolescent fairy tale, one filled with lyrical turns like this one, from "Damien":

Junice moves uneasily through the room

Her stops punctuated by a soft smile

That sends shivers of delight up my spine

My smile doesn't fit my face anymore 
Clumsily I try to hold the space

She gives me between the yellowed curtains

And the darkly stained table where my legs

Cross and uncross searching out casual

The smell of food cooking in some other

Kitchen reminds me that we share the world (74)

Or this, from "Junice in the Supermarket":

He strews his path with prose

And expects me to skip from verb to noun

Making garlands of his wit

How dare he hi-yo-Silver me when I am so

Needy, my palms turned up in begging

Lágrimas de luna por favor. (37)

Myers is not the only children's poet this year who embraces multiple languages, who seeks to coax children across linguistic and cultural divides with sensitively rendered lyric poetry. In his honor book Talking with Mother Earth/Hablando con Madre Tierra, Jorge Argueta provides facing page versions of the poems in Spanish and English, along with idioms from Nahuatl, to create a linguistic texture impossible in monolingual texts. Furthermore, Argueta plays with language and subjectivity in a fashion that achieves a lovely balance between two competing impulses in contemporary poetry. The first of these impulses, commonly found in adult poetry, is to revel a bit excessively in the lyric " $\mathrm{I}$ " and its attendant narcissism. The second-more common in children's poetry - is to shy away from the lyric "I" altogether, as if children cannot be trusted with other lives and other minds. Talking with Mother Earth achieves this balance by speaking in the highly personal voice of a young Pipil Nahua Indian. These poems don't seek to educate children about what it means to be a Pipil Nahua Indian, though they may have this residual effect. Rather, they work on a more intimate (and less didactic) level, sharing one boy's experience:

-En este pueblo,

me dijo mi mamita Wicha

cómo se llama en nahuatl

mi abuelita Luisa.

Nanny Wicha

is what we call

my grandmother Luisa

in Nahuatal.

("Lengua/Tongue" n.p.) 
In other poems, the experiences are more painful:

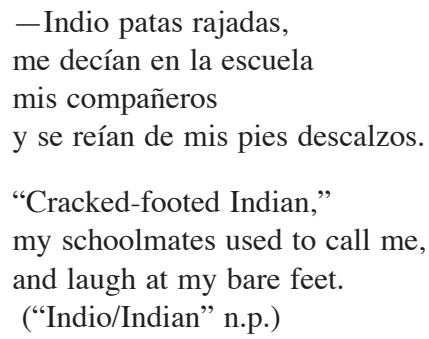

In a prose narrative, the two scenes - of family intimacy, and of schoolyard racism - would have to be somehow integrated or resolved. In a book of poems such as this, intimacy and racism can dwell in tension with each other: the poet moves between worlds and between languages, capturing disparate moments in brief bilingual lyrics. Moreover, the racism depicted is not distanced from the present moment, so that, unlike so many children's books that "celebrate diversity," these poems confront the hard issues head-on. Argueta, a Salvadoran and Pipil Nahua Indian now living in San Francisco, provides his own English translations, and he has a fine ear for both English- and Spanish-language poetry. Unfortunately, while we admire Lucía Angela Perez's illustrations, we do think the design of the book is flawed. Too often, the poems are printed right on top of the illustrations, which is visually overwhelming and sometimes makes the poems hard to read.

Our winner, however, excels as poetry and as a material object. JonArno Lawson's Black Stars in a White Night Sky is a beautifully designed book filled with well-crafted poems. It's a good sign that JonArno Lawson's book has a blurb from an authentic poet, X. J. Kennedy, and not just a celebrity endorsement from such as Jane Seymour or Fergie. We think that children's poetry is poetry, and that poets from the wider world of poetry should mix more often with poets whose work may also be marked as being "for" children. We should also mention that the wider world of poetry is still not very wide, and people do tend to know one another. As it happens, two of the three judges this year came to know Lawson personally after his previous collection, The Man in the Moon-Fixer's Mask was named an honor book for the 2005 award. The judges were so impressed with his poetic talent and knowledge that he was invited and agreed to serve as a judge for the 2006 award. Foetry.com, the muckraking website that roots out corruption in contests (the National Poetry Series, the Vassar Miller Prize) should have a field day with The Lion and the Unicorn this year-and we hope they take children's poetry seriously 
enough to notice! Ultimately, however, we awarded Lawson the prize not because of our connections with him, but in spite of them. And Angela Sorby, who has no previous link to Lawson, independently came to the same conclusion: inescapably, Black Stars in a White Night Sky (Fig. 2) is the best of the bunch.

Lawson is in a class by himself: he plays, but he does not pander. His book is a lot of smart fun because it keeps changing gears. It opens with "An Adventure Begins," an evocative poem that embraces the darkness so often elided by contemporary children's poets. Varying long lines with short, Lawson begins the poem sweetly:

An adventure begins,

when one who was grimacing

suddenly grins. (15)

But he quickly turns from the light to the dark, noting that, yes, adventure begins "when the one who was losing / suddenly wins," but also that adventure begins "when the one who acts saintly / suddenly sins." With this line, the earlier lines begin to flicker: what prompted that grin in line three? And the loser in line five - what's he losing? And winning? Adventures are dangerous, unpredictable things, often beginning with trouble and travail, "when the smooth surface pops up with circling fins." But that doesn't mean we don't like them.

Some of his poems are indebted to the nonsense of Edward Lear:

"I wasted my youth

on the Malabar coast,

on a pepper plant

tied to a pepper plant post."

(“The Peppercorn" 78)

And some are more contemporary:

How, without arms,

did the sun

climb over the trees?

And, without knees

to sink on,

how did it sink behind them?

("How Without Arms" 60)

But even when the poems show their influences (Lear, Silverstein) they are strikingly original. One of Lawson's strengths is finding distinctive topics: no cycle of poems about holidays for him. Instead, he lets the language lead, reminding us at times of an unstuffy early Wallace Stevens: 


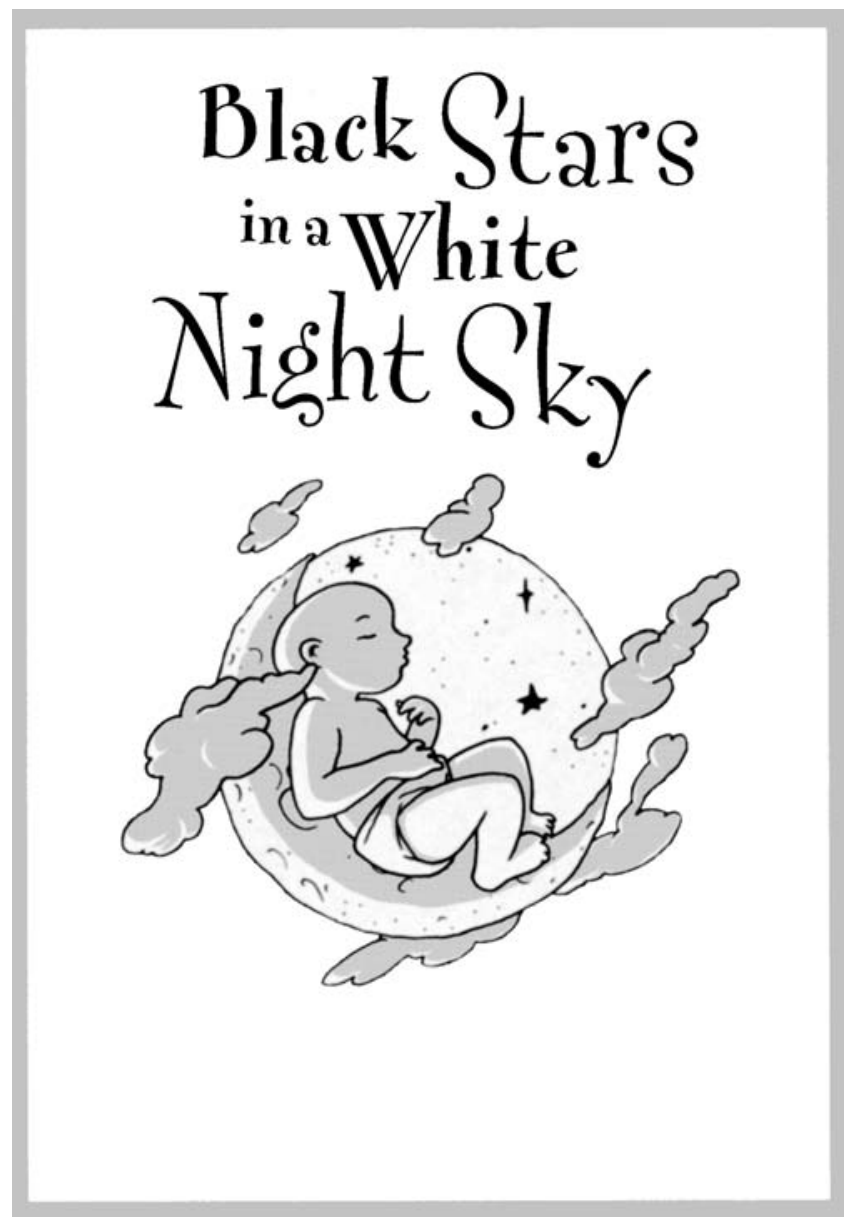

Figure 2. Sherwin Tija's illustration for "Black Stars in a White Night Sky," Black Stars in a White Night Sky by JonArno Lawson (Toronto: Pedlar Press, 2006). Reproduced with permission of Pedlar Press.

Tickle tackle Botticelli

chirping cockatoo

chock a lick a chocolate drop

kockamamie moo.

(“Tickle Tackle Botticelli" 116)

To which Stevens would reply: Henna hackles halt!

Of course, because Lawson tries on so many thematic and stylistic hats, he's not entirely consistent. To our ears, a few fall flat, such as "Eat a Duck": 
Eat a duck, quack quack, eat a duck, quack quack, when you're hungry and you really need a snack, quack quack. (46)

To which we say: ack. But perhaps some unevenness is the price we pay for a truly inspired (as opposed to market-inspired) book. This is even a strength, in the sense that the collection isn't too slick. Could Lawson's status as a Canadian writer-perhaps slightly removed from the commercial energies of the United States - be a factor? (And we might add here that both Argueta and Lawson are published by Canadian presses. In fact, Anansi, founded by Dennis Lee, initially published poets including Margaret Atwood and Michael Ondaatje, and Groundwood is run by the widow of another Canadian poet/novelist, Matt Cohen.) At any rate, Lawson's slight roughness is notable and at times even pleasing. And there are many, many unequivocal hits here. One high point is the mildly ominous "Faster and Faster and Faster She Went," which starts in medias res:

Faster and faster and faster she went, and all she rolled over got broken and bent.

Who on earth was she and why was she sent? (111)

By the end of the poem this girl has "flattened, destabilized, [and] halfdestroyed" the world-and has been, inexplicably, forgiven. Here and elsewhere Lawson bravely engages with the dark side of childhood-not excessively or ghoulishly, but just enough to remind us that it's not all lollipops and turkey pie.

Lawson also possesses what few poets for the young demonstrate: a truly subversive wit. Too often the subversive side of children's poems is tamed by an implicit or explicit moralizing, as if the adult poet can let children get away with only so much before reasserting his or her adult authority. In contrast to poets who always have one ear to the ground in order to make sure that parents or teachers don't get too upset, Lawson gives us "Handsome Prince":

"Go on, kiss her,

handsome prince, don't treat it like a duty!

What man wouldn't envy you

for kissing Sleeping Beauty?"

"I'm sorry, but I can't,"

the handsome prince said, eyes a-twinkle,

"My heart, my soul and waking kiss

belong to Rip Van Winkle." (112) 


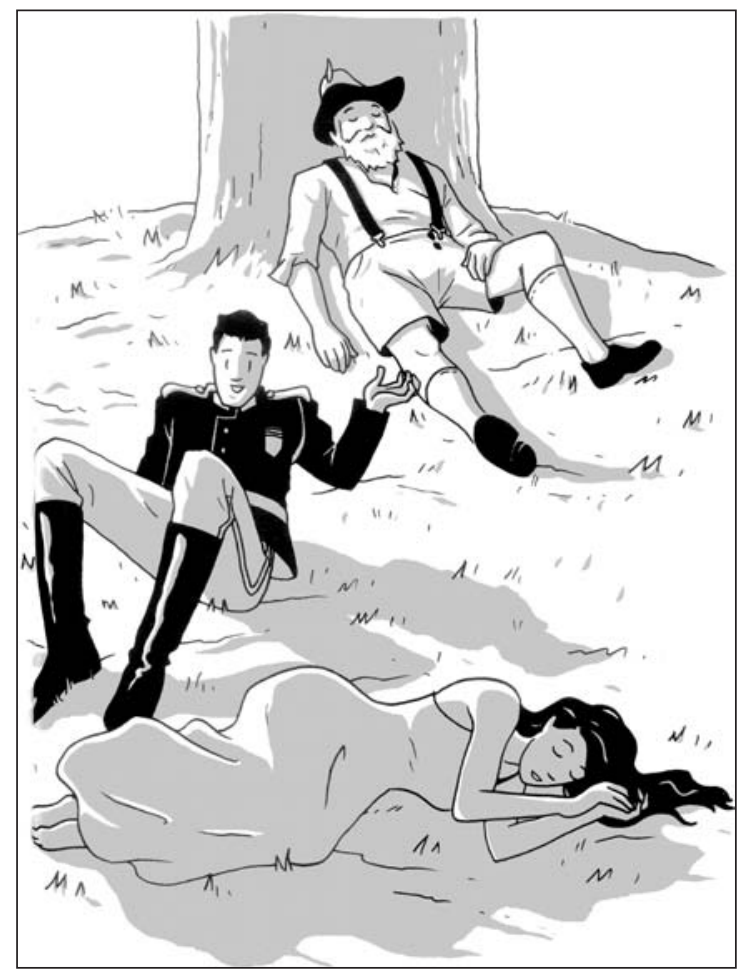

Figure 3. Sherwin Tija's illustration for "Handsome Prince," Black Stars in a White Night Sky by JonArno Lawson (Toronto: Pedlar Press, 2006). Reproduced with permission of Pedlar Press.

The excellence of Sherwin Tjia's illustration (Fig. 3) complements this striking poem: while his portrayal of the threesome is comic, it nevertheless emphasizes the tenderness of the relationship between the prince and Rip as their hands gesture toward one another, anticipating the breaking of the spell, while Sleeping Beauty, her back turned to them, slumbers on.

Finally, Lawson's tonal range is impressive indeed. While he is undoubtedly one of today's most gifted poets of humorous and nonsense verse , he is also capable of lyric moments that ring true-as in "The First Real Warmth":

Dead leaves

and seeds

winter inters:

with the first real warmth 


\section{What's dead \\ falls apart, \\ what's living \\ stirs. (57)}

The way that Lawson manages the quiet music of this poem confirms for us that he is the real thing. For Lawson is not just the master of the pyrotechnical display. His talent for rollicking nonsense comes from the same care and attention to language he displays in this provocative lyric. The echoing "winter inters" is brilliant enough, but the management of the final rhyme with "stirs" is expertly deferred. The longest seemingly out of place line "with the first real warmth" strikes one as prosaic until one notices how it resonates with the other words in the poem. Yet for all the rich assonance and internal rhyme in this poem, the two large abstract concepts have no rhymes: "dead" chimes with itself, and "living" stands sonically apart from the rest of the poem. And speaking of "apart," the lines "What's dead / falls apart" are chilling in their hardnosed simplicity.

Lawson has heeded the messages in the bottle received from midtwentieth century masters like Hoberman, Brooks, and Wilbur. And if we may be permitted a mixed metaphor, he has concocted new wine for that bottle. While we can't predict the future, we wouldn't be at all surprised if, on some future desert island, a child Crusoe encounters his work and that of the other fine poets honored this year and says, "So this is poetry? It tastes good to me."

Angela Sorby is Associate Professor of English at Marquette University, where she teaches literature and creative writing. Her books are Schoolroom Poets: Childhood, Performance, and the Place of American Poetry (UP of New England, 2005) and Distance Learning: Poems (New Issues Press, 1998). Schoolroom Poets was recently named a 2007 Honor Book by the Children's Literature Association. Her new collection of poems, Flyover State, is forthcoming from Parallel Press/University of Wisconsin (Madison).

Joseph T. Thomas, Jr. has recently joined the faculty at San Diego State University, where he teaches children's literature. A poet and scholar, Thomas is author of Poetry's Playground: The Culture of Contemporary American Children's Poetry (Wayne State UP, 2007) and Strong Measures Los Angeles: Make Now Press 2007). He has published essays in Style, Children's Literature, The Horn Book Magazine, Children's Literature Association Quarterly, The Lion and the Unicorn, Studies in the Novel, and Reconstruction, among other places. His book on Shel Silverstein: The Devil's favorite pet: Shel Silverstein, an American Iconoclast is a work in progress. 
Richard Flynn is Professor of Literature at Georgia Southern University, where he teaches children's literature and modern and contemporary poetry. He is the author of Randall Jarrell and the Lost World of Childhood (U Georgia P, 1990) and a collection of poems, The Age of Reason (Hawkhead P, 1993). He has published articles on such poets as Muriel Rukeyser, Elizabeth Bishop, Gwendolyn Brooks, and June Jordan in Children's Literature, African American Review, and other books and journals. He is the editor of The Children's Literature Association Quarterly, and is completing an essay titled "The Fear of Poetry" for the Cambridge Companion to Children's Literature.

\section{Works Cited}

Apollinaire, Guillaume. "Il Pleut," Calligrammes: Poems of Peace and War (1913-1916). Berkely: University of California Press, 1980.

Argueta, Jorge. Talking with Mother Earth/Hablando con Madre Tierra. Illus. Lucía Angela Pérez. Toronto: Groundwood/House of Anansi, 2006.

Florian, Douglas. Handsprings. Illus. Douglas Florian. New York: Greenwillow/ HarperCollins, 2006.

Frost, Helen. The Braid. New York: Frances Foster/Farrar Straus: 2006.

Jarrell, Randall. No Other Book: Selected Essays. Ed. and Intro. Brad Leithauser. New York: Michael di Capua/HarperCollins, 1999.

Jones, LeRoi. Blues People: Negro Music in White America. New York: Harper Perennial, 1999 [1963].

Lawson, JonArno. Black Stars in a White Night Sky. Illus. Sherwin Tjia. Toronto: Pedlar Press, 2006.

Myers, Walter Dean. Jazz. Illus. Christopher Myers. New York: Holiday House, 2006.

Street Love. New York: Amistad/HarperTempest, 2006.

Perloff, Marjorie. Radical Artifice: Writing Poetry in the Age of Media. Chicago: U of Chicago P, 1991.

Shannon, George. Busy in the Garden. Illus. Sam Williams. New York: Greenwillow/HarperCollins, 2006.

Shore, Diane Z., and Jessica Alexander. This is the Dream. Illus. James Ransome. New York: Amistad/HarperCollins, 2006.

Winter, Jonah. Dizzy. Illus. Sean Quails. New York: Arthur A. Levine, 2006.

Yolen, Jane, ed. This Little Piggy and Other Rhymes to Sing and Play. Illus. Will Hillenbrand. Musical Arrangements by Adam Stemple. Cambridge, MA: Candlewick, 2005. 